\title{
Feedbacks between deforestation, climate, and hydrology in the Southwestern Amazon: implications for the provision of ecosystem services
}

\author{
Letícia S. Lima • Michael T. Coe • Britaldo S. Soares Filho \\ Santiago V. Cuadra - Lívia C. P. Dias - Marcos H. Costa • \\ Leandro S. Lima $\cdot$ Hermann O. Rodrigues
}

Received: 17 April 2013/ Accepted: 19 November 2013

(C) Springer Science+Business Media Dordrecht 2013

\begin{abstract}
Forests, through the regulation of regional water balances, provide a number of ecosystem services, including water for agriculture, hydroelectric power generation, navigation, industry, fisheries, and human consumption. Large-scale deforestation triggers complex non-linear interactions between the atmosphere and biosphere, which may impair such important ecosystem services. This is the case for the Southwestern Amazon, where three important river basins (Juruá, Purus, and Madeira) are undergoing significant land-use changes. Here, we investigate the
\end{abstract}

Electronic supplementary material The online version of this article (doi:10.1007/s10980-013-9962-1) contains supplementary material, which is available to authorized users.

L. S. Lima $(\bowtie) \cdot$ B. S. Soares Filho ·

L. S. Lima - H. O. Rodrigues

Centro de Sensoriamento Remoto, Universidade Federal

de Minas Gerais, Av. Antônio Carlos, 6627, Belo

Horizonte, Minas Gerais 31270-900, Brazil

e-mail: leticialima@ymail.com; leticialima@csr.ufmg.br

B. S. Soares Filho

e-mail: britaldo@csr.ufmg.br

L. S. Lima

e-mail: leandro.stlima@gmail.com

H. O. Rodrigues

e-mail: hermann@csr.ufmg.br

M. T. Coe

The Woods Hole Research Center, 149 Woods Hole

Road, Falmouth, MA 02540-1644, USA

e-mail: mtcoe@whrc.org potential impacts of deforestation throughout the Amazon on the seasonal and annual water balances of these river basins using coupled climatic and hydrologic models under several deforestation scenarios. Simulations without climate response to deforestation show an increase in river discharge proportional to the area deforested in each basin, whereas those with climate response produce progressive reductions in mean annual precipitation over all three basins. In this case, deforestation decreases the mean annual discharge of the Juruá and Purus rivers, but increases that of the Madeira, because the deforestation-induced reduction in evapotranspiration is large enough to increase runoff and thus offset the reduction in precipitation. The effects of Amazon

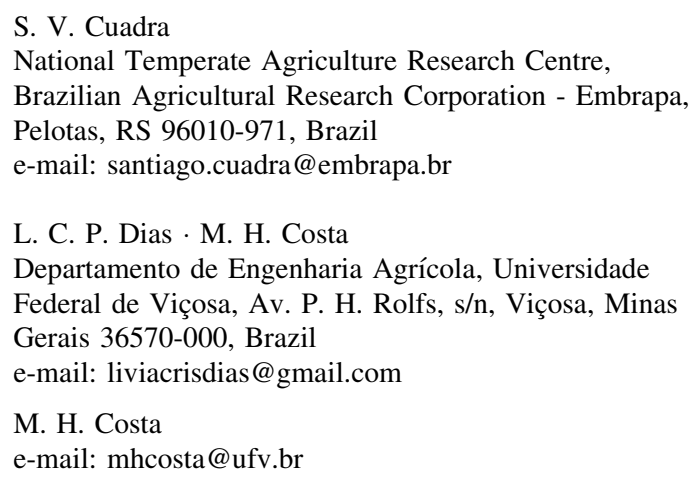


deforestation on river discharge are scale-dependent and vary across and within river basins. Reduction in precipitation due to deforestation is most severe at the end of the dry season. As a result, deforestation increases the dry-season length and the seasonal amplitude of water flow. These effects may aggravate the economic losses from large droughts and floods, such as those experienced in recent years $(2005,2010$ and 2009, 2012, respectively).

Keywords Landscape dynamics - Water balance $\cdot$ Land change simulation $\cdot$ DINAMICA EGO $\cdot$ THMB

\section{Introduction}

The regulation of the water balance and river flow by forests provides ecosystem services that are economically valuable and critical for sustaining agriculture, hydroelectric power, industry, fisheries, river navigability, urban dwellings (Guo et al. 2000; Postel and Thompson 2005; Castello et al. 2013) and important non-use values, such as ecotourism (Kirkby et al. 2011) and recreational opportunities (Millennium Ecosystem Assessment 2005). Soil water and surface waters-including runoff, discharge and water stored in lakes-play an important role in supporting ecosystems and biodiversity by providing nutrients and habitats for many species. Rivers are important in biogeochemical reactions and are responsible for transporting large amounts of carbon and nitrogen (Meybeck 1982; McClain et al. 2003). Forest clearing for agricultural expansion and infrastructure development directly or indirectly alter the water balance of river basins, and as a result may impair forest ecosystem services (Costa and Foley 2000; Malhi et al. 2008; Coe et al. 2009).

This is the situation for Southwestern Amazon, where Amazon countries are undertaking large infrastructure projects (Killeen 2007). This region (Fig. 1), where the departments of Madre de Dios in Peru, Acre in Brazil, and Pando in Bolivia meet (thus known as MAP) is one of the most biologically and culturally diverse regions of the world (Mittermeier et al. 2003; Brooks et al. 2006; Perz et al. 2008). The Southwestern Amazon encompasses the headwaters of three important river basins - the Juruá, Purus, and Madeira - that contribute $\sim 24 \%$ of the discharge of the Amazon
River and drain an area of $\sim 2$ million $\mathrm{km}^{2}$. Much of the region is still covered by native savannas and tropical forests of which $40 \%$ are used for harvesting timber (Giudice et al. 2012) or non-timber forest products such as Brazil-nut (Nunes et al. 2012). Protected areas in the region include indigenous territories that are home to some of the world's last remaining uncontacted indigenous tribes (Survival International Charitable Trust 2012), as well as conservation areas that are becoming increasingly important ecotourism destinations (Kirkby et al. 2011). In addition, recent archeological findings of earthworks and geoglyphs dating from over 1,000 years ago (Mann 2008) underscore the historical importance of this region.

Large investments in infrastructure, supported by multilateral financing mechanisms such as the Initiative for the Integration of Regional Infrastructure in South America-IIRSA (Killeen 2007), are increasingly changing the landscapes of the Southwestern Amazon. Together with the expansion of cattle ranching, agriculture, oil and gas concessions (Finer et al. 2008), and gold mining (Swenson et al. 2011), these investments may already be impairing the region's forest ecosystems and as a result the local economies that depend upon them. In particular, the paving of the Interoceanica Sur highway (Perz et al. 2008; Southworth et al. 2011) and the construction of hydroelectric power plants (Jirau and Santo Antonio in the Madeira basin, Brazil) and other planned ones (e.g. Inambari in Madre de Dios, Peru) are boosting regional economies (Finer and Jenkins 2012), accelerating migration to the region, and thus spurring deforestation that may alter the regional climate and water balance. Hence these projects may fail to improve welfare in the region and elsewhere as they have the potential to cause large losses of ecosystem services due to feedbacks between land-cover change, climate, and hydrology.

Policymakers have largely overlooked the disruption of ecosystem services-such as water balance and climate regulation (Anderson-Teixeira et al. 2012) that may likely ensue from development plans like IIRSA. Their unseen consequences may eventually compromise the social and economic benefits expected from those policies. In order to avoid such undesirable results, there is a need to identify the role of forests in maintaining ecosystem services. This can help improve and support integrated environmental management in changing landscapes. In this study, we address the 
Fig. 1 Study area. Numbers indicate river discharge monitoring stations used to validate model simulations (additional details on Supplementary Material)

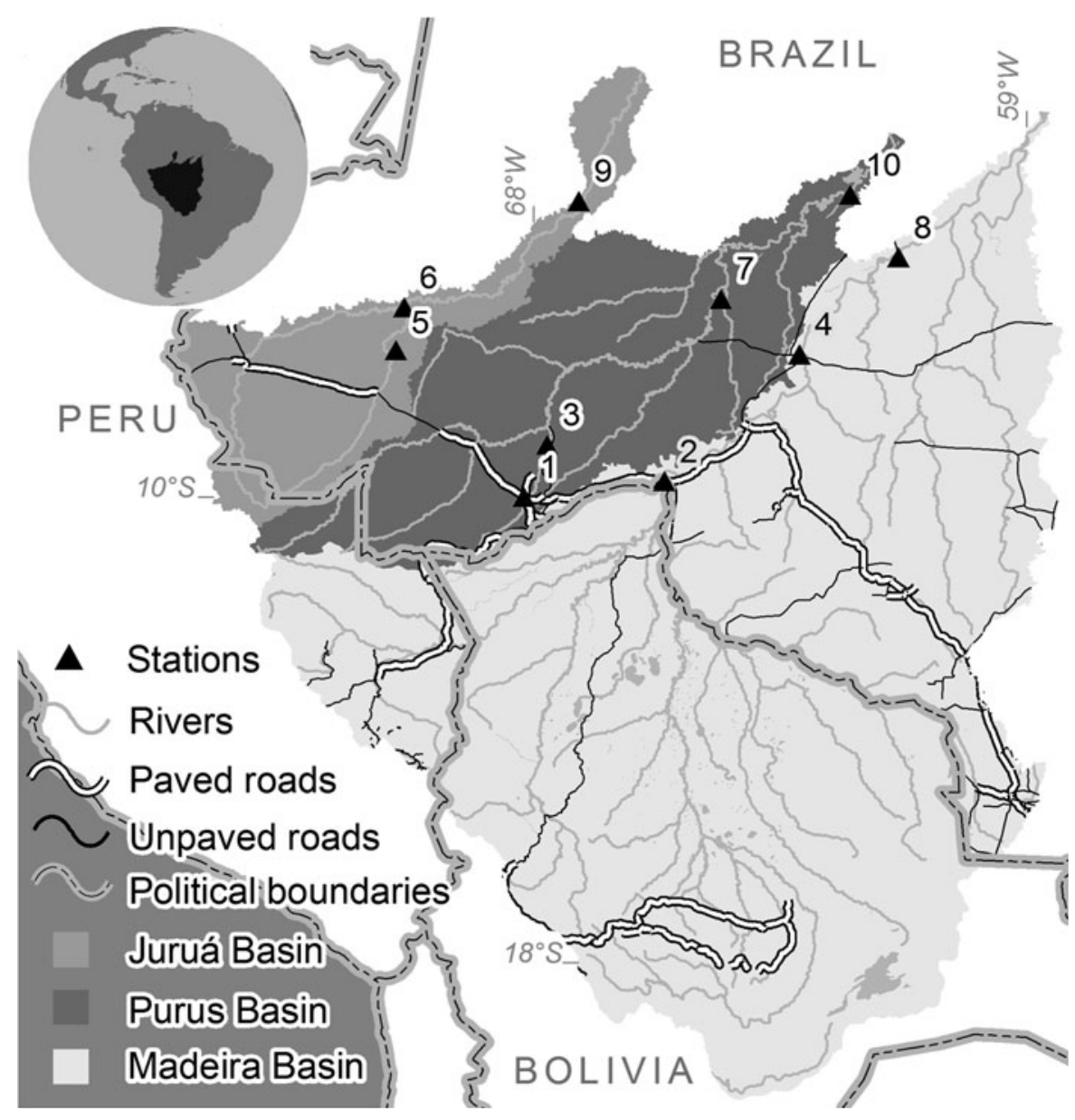

potential impacts of deforestation throughout the Amazon on the seasonal and annual water balance of Juruá, Purus, and Madeira river basins as a means of drawing attention to the need for reconciling conservation with sustainable development in the Southwestern Amazon.

\section{Materials and methods}

\section{IBIS land surface model}

The integrated biosphere simulator (IBIS) (Foley et al. 1996; Kucharik et al. 2000) is a dynamic global ecosystem model that simulates biosphere-atmosphere interactive processes, such as energy, water, and carbon exchanges among soil, vegetation, and the atmosphere. The physical equations have an hourly time step. Other processes, such as carbon allocation and phenology, operate on a daily to yearly basis. Solar radiative balance at the surface is calculated using the two-stream approximation for each plant functional type (PFT), considering direct and diffuse radiation in visible and near-infrared wavelengths. Hydrological processes simulated within the model include precipitation interception and retention by the canopy, surface puddle formation, soil infiltration, water flux between soil layers, deep percolation, root water uptake, canopy transpiration, and evaporation from the soil surface and canopy. IBIS spatially explicit simulates surface and subsurface runoff as a function of soil, vegetation, and climate characteristics, and calculates differences between precipitation and atmospheric and plant water demand. Horizontal transport of water between grid cells is subsequently simulated by the Terrestrial Hydrology Model with Biogeochemistry (THMB) river transport model. The spatial resolution of this simulation is 5 arc-min, corresponding to $\sim 9 \mathrm{~km}$ near the equator. 
THMB river transport model

The Terrestrial Hydrology Model with Biogeochemistry (THMB) (Coe et al. 2002, 2007) is a physicallybased, distributed, flow-routing model that predicts river discharge and the spatial distribution of water level and water area of large lakes and wetlands. Water volume and flow are calculated based on a linear reservoir approach (Vörösmarty et al. 1989; Miller et al. 1994). The model uses prescribed river paths and morphology data to simulate water velocity and water levels (Coe et al. 2007). THMB uses surface and subsurface runoff grid data from IBIS as input. The slope and river paths are derived from digital elevation maps. In our simulations, temporal and spatial resolutions are set, respectively, to a 1-h time step and to 5 arc-min $(\sim 9 \mathrm{~km})$. In this study, we employ a version of THMB developed using the Dinamica EGO graphical interface (Lima Leticia et al. 2013).

\section{CCM3 atmospheric model}

The Community Climate Model version 3 (CCM3) (Kiehl et al. 1998) is an atmospheric general circulation model from the National Center for Atmospheric Research (NCAR). In our simulations, we use CCM3 coupled to IBIS. We refer to this coupled model as CCM3-IBIS (Delire et al. 2002). We set CCM3 at a resolution of T42L18 (the spectral representation of the horizontal fields is truncated at the 42 nd wavenumber using a triangular truncation; horizontal fields are converted to a $2.81 \times 2.81^{\circ}$ grid; 18 levels in the vertical), with a 20 -min time step.

\section{Data}

Amazon atmospheric conditions for the period of 1950-1999 were from the CRU3.0 dataset (Mitchell and Jones 2005) and consist of monthly air temperature, precipitation, vapor pressure, and cloud cover data. The digital elevation model (DEM) used in the study to calculate water velocity has 5 arc-min $(\sim 9 \mathrm{~km})$ spatial resolution and is resampled from HydroSHEDS database (Lehner et al. 2008), which is primarily based on Shuttle Radar Topography Mission data. The maps of river flow directions and flow accumulation derived from the DEM are manually corrected based on high-resolution river mapping from the Brazilian Water Agency (Agência Nacional de
Águas, ANA). We also create basin masks from the flow accumulation map and correct them based on the ANA watershed maps (HidroWeb, http://hidroweb. ana.gov.br/). Observed river discharge data come from the same source. We use geomorphic relationships between drainage area and river channel features derived for the Amazon basin by Coe et al. (2007) and a sinuosity parameter as in Costa et al. (2002) to characterize river system morphology.

\section{Land cover scenarios}

We use four different deforestation scenarios in the simulations (Fig. S1, Supplementary Material): (i) End of Deforestation by 2020 (ED2020, Nepstad et al. 2009); (ii) Business-as-Usual (BAU) deforestation scenario by 2030 (BAU2030); (iii) BAU deforestation by 2050 (BAU2050, Soares-Filho et al. 2006); and (iv) a Control (CTL) scenario, in which the vegetation cover remains as it would be without anthropogenic change (Ramankutty and Foley 1998). ED2020 considers that deforestation will end as a result of governance efforts, including law enforcement, market exclusion of deforesters, and effective management of protected areas (Nepstad et al. 2009; Soares-Filho et al. 2010). BAU2030 and BAU2050 scenarios assume that deforestation rates at the beginning of 21 st century will continue into the future due to investments in infrastructure under a context of low compliance with environmental laws and lax enforcement of protected areas (Soares-Filho et al. 2006).

\section{Experimental design}

In the Control simulation, we run a set of simulations on IBIS without changes of land cover or natural vegetation (CTL land cover scenario). Atmospheric conditions are prescribed from CCM3 simulations for the period 1950-1999 based on historical data. We remove bias in monthly air temperature, precipitation, water vapor pressure, and cloud cover simulated from CCM3 by using the CRU3.0 dataset (Mitchell and Jones 2005). Then we run two sets of simulations using IBIS stand-alone and the coupled IBIS-CCM3 to evaluate the direct (no climate feedback-referred to as LCC_NoCF) and indirect (with climate feedbackreferred to as LCC_CF) impacts of land cover changes. Land cover is kept static for each modeled scenario. As in Costa et al. (2007), natural vegetation 
is replaced by tropical grasses ( $\mathrm{C} 4$ species) in deforested areas.

In the LCC_NoCF set of simulations, IBIS standalone is forced with historical atmospheric conditions (as in the CTL simulation) and three deforestation scenarios (ED2020, BAU2030, and BAU2050). No climate feedbacks to land cover changes are considered. In the LCC_CF set of simulations, the coupled IBIS-CCM3 models are forced with the three land cover scenarios to simulate the atmospheric responses to changing land-cover and associated climate feedbacks - the effects of deforestation on CCM3 monthly air temperature, vapor pressure, precipitation, and cloud cover-as well as the direct land cover impacts. Finally, THMB simulates river discharge. The deforestation scenarios used in the IBIS-CCM3 simulations cover the entire Amazon biome, in recognition of the fact that climate feedbacks may not only be related to changes in Southwestern Amazon, but also to deforestation throughout the Amazon (Supplementary Material, Fig. S1).

\section{Results}

No climate feedbacks

The LCC_NoCF simulations consider no climate feedbacks from deforestation. The replacement of native forest by grasses alters biophysical properties, decreasing leaf area index (LAI) and plant rooting depth (Bonan 2008), which in turn contribute to reduced evapotranspiration (ET). We compare the main hydrological changes in each basin against the percentage of deforested area of each scenario (Table 1). Relative differences are expressed in comparison to the CTL simulation. The LCC_NoCF simulations show a decrease in ET rates proportional to the deforested area in each basin. The simulated ET is reduced by as much as $13 \%$ over the three basins under BAU2050.

In the absence of climate feedbacks, river discharge increases significantly in the three basins as a result of the ET decrease, becoming more pronounced when deforestation exceeds $20 \%$ (Table 1; Fig. 2a) of the basin area. Annual river discharge increases by $21 \%$ in the Juruá, $23 \%$ in the Purus, and $31 \%$ in the Madeira under BAU2050 (stations number 9, 10, and 8 in Fig. 1, respectively).
With climate feedbacks

Coupled CCM3-IBIS simulations considering climate feedbacks from deforestation (LCC_CF) show that interactions between altered land surface and atmospheric circulation and convection over the Amazon basin result in complex changes in the water balance of the three basins, because these interactions affect both ET and precipitation $(\mathrm{P})$.

\section{Annual mean results}

From the least deforested (ED2020) to the most deforested (BAU2050) scenario, the simulation results show a progressive reduction in annual mean $\mathrm{P}$ (Table 1). Under the ED2020 scenario, P decreases by $4 \%$ over the Purus and Juruá basins and by $7 \%$ over the Madeira basin. Under BAU2050, P decreases by $15 \%$ over the Juruá, $14 \%$ over the Purus, and $9 \%$ over the Madeira.

In most scenarios, ET decreases progressively with the increase in deforested area reaching a reduction of $13 \%$ in the Juruá basin, $12 \%$ in the Purus basin and $17 \%$ in Madeira basin. However, in the Purus and Juruá basins there is a slight increase in ET in the ED2020 scenario relative to the CTL simulation, despite a decrease in precipitation (Table 1). The ET increase results from higher ET over forest areas, most likely due to the small precipitation reduction over those basins (-4\%, ED2020), which slightly increases incident solar radiation (due to decreased cloud cover). In this case, the P decrease is not large enough to provoke extended water stress in the preserved forest area.

The annual mean discharge of the Purus and Juruá rivers is reduced in all deforestation scenarios in comparison to CTL. Reductions vary from $13 \%$ (ED2020) to as much as $18 \%$ (BAU2050) (Table 1; Fig. 2b). The response of the Madeira River is considerably different, with a modest simulated decrease in discharge under the ED2020 scenario (3\%) and a $12 \%$ increase under BAU2050. This increase is associated with a large decrease in simulated ET rates in the Madeira basin, which is greater than the simulated decrease in P. These differences in mean discharge among basins are a result of a complex interaction between vegetation cover and climate. First, it is worthy of note that forests are predominant in the Purus and Juruá, whereas in the 


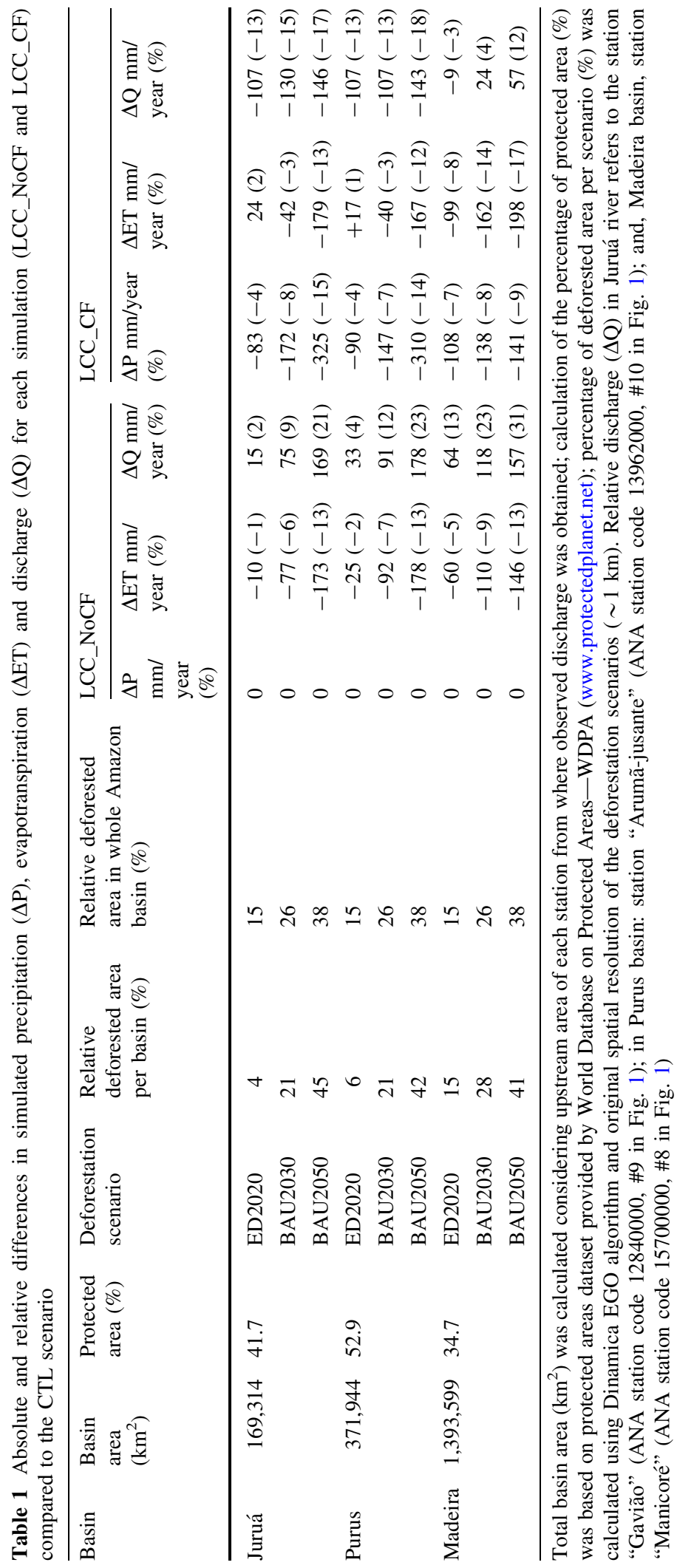



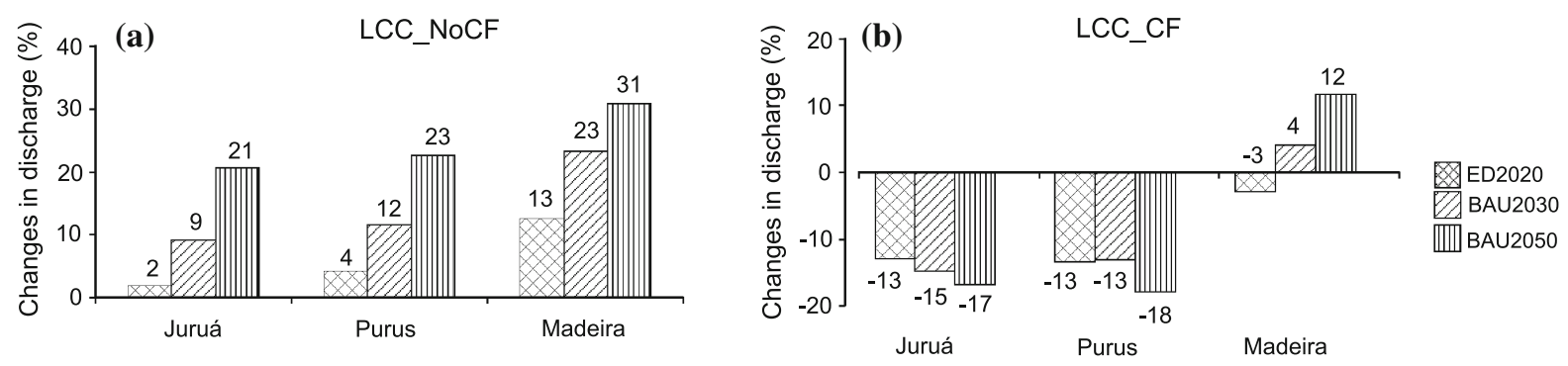

Fig. 2 Changes in average river discharge relative to the CTL simulation for the three basins: a LCC_NoCF simulations. b LCC_CF simulations. Discharge values obtained at points 9 (Juruá River), 10 (Purus River) and 8 (Madeira River) according to Fig. 1

Madeira basin a significant fraction of the area is composed of savannas-see Supplementary Fig. S1. Another noticeable difference is related to the climate anomalies associated with the deforestation scenarios. The CCM3 simulates relatively homogenous climate anomalies over the Purus and Juruá basins, with a general decrease of precipitation. On the other hand, precipitation in the Madeira basin is reduced over the central and northern portions, but increased over the southern portion.

To analyze the effect of scale on hydrological alteration, we also evaluate changes in discharge of the Acre River (station number 1, Fig. 1), which is located in the southern portion of the Purus basin and accounts for $\sim 3 \%$ of the discharge of the Purus River. The discharge of the Acre River increases by up to $73 \%$ under BAU2030 and $36 \%$ under BAU2050. This increase is due to the large reduction in ET from extensive deforestation in this watershed that offsets decreases in P.

Seasonal mean results. Deforestation-induced decreases in precipitation are pronounced during the transition between dry and wet seasons (SeptemberNovember) in all three basins, but they are also evident during the dry season (June-August) in the Madeira and Purus basins (Fig. 3). During the transition period, precipitation decreases by more than $30 \%$ under BAU2050 in the Juruá and Purus basins. September is the month with the greatest changes in precipitation rates, which decrease from $4.3 \mathrm{~mm} /$ day in the CTL to $1.6 \mathrm{~mm}$ /day over Juruá basin, from 4.0 to $1.8 \mathrm{~mm}$ /day over Purus basin, and from 2.6 to $1.5 \mathrm{~mm} /$ day over Madeira basin (Supplementary Table S3). Although the effects during the dry and transition seasons are more intense, precipitation also decreases in the Juruá and Purus basins during the wet season-mainly in February and March-by up to $1 \mathrm{~mm} /$ day under BAU2050.
The simulations show an overall reduction in the difference between precipitation and evapotranspiration (P-ET) in the Purus and Juruá basins and a slight increase in the Madeira basin as deforestation progresses, especially under BAU2050. As a result of these changes, the length of the water deficit period (months when P-ET $<0$ ) is extended in the Purus and Juruá basins by half a month under ED2020 and up to 1 month under BAU2030 and BAU2050 (Fig. 4). Almost no difference in the length of the water deficit period is simulated for the Madeira Basin.

The increase in water-deficit period directly impacts the seasonal discharge of the main rivers. The Juruá River discharge decreases by $35 \%$ during September and October under BAU2050, whereas the Purus River October discharge decreases by $30 \%$ under BAU2030 and $35 \%$ under BAU2050. Additional details on validation and comparison of our results with those from previous studies can be found in the Online Supplementary Material.

\section{Discussion}

Weighting local and regional effects of deforestation

Forests play a key role in regulating annual and seasonal water balance. By comparing scenarios without the influence of land cover changes on climate (LCC_NoCF) with those with climate feedbacks (LCC_CF), we show that local deforestation within the basin (as in LCC_NoCF) has a correlation with river discharge. On the other hand, large-scale deforestation can indirectly impact regional climate (as in LCC_CF), leading to complex feedbacks and variable responses in river flow. 
Fig. 3 LCC_CF

simulations: mean seasonal changes in precipitation rates relative to the $\mathrm{CTL}$ simulation for each basin. Dry season (June, July, August), early wet season (September, October, November), wet season core (December, January, February), and late wet season (March, April, May)
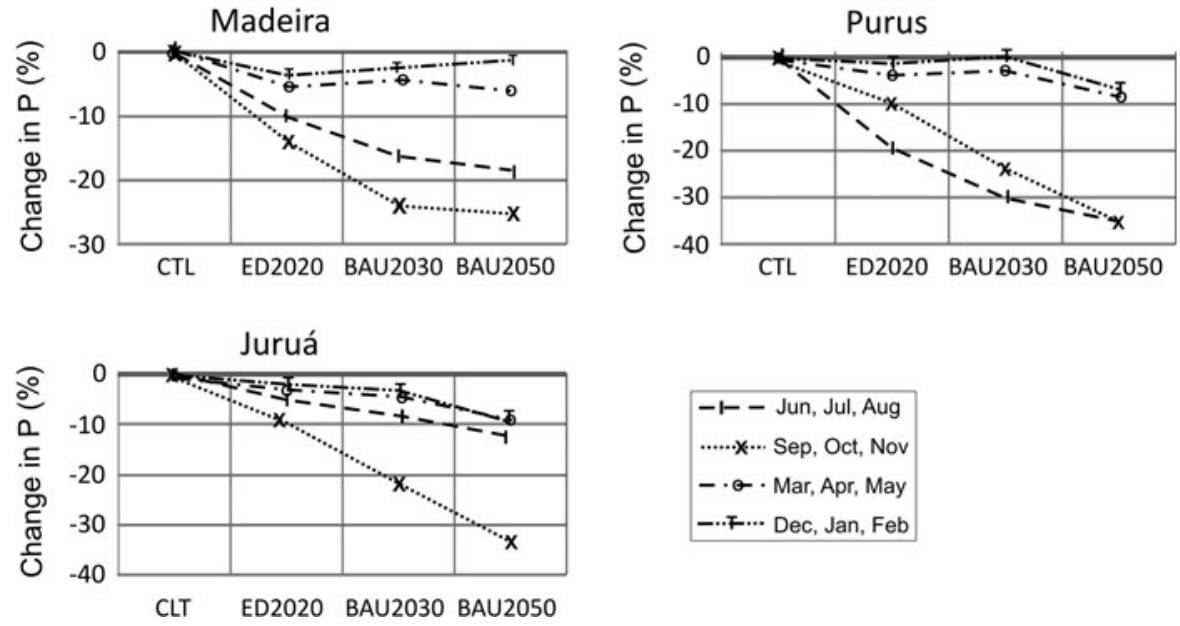

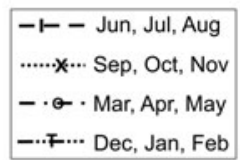

Juruá

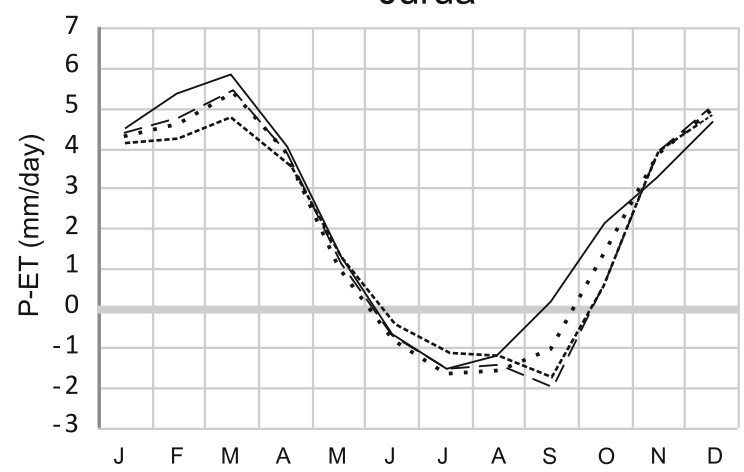

Madeira

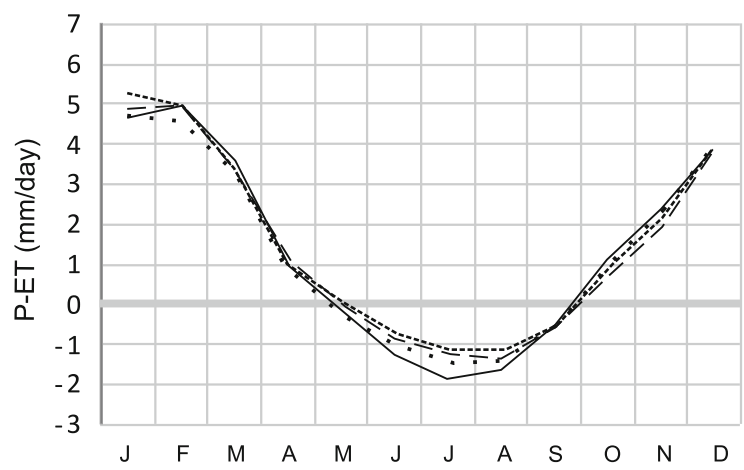

Purus

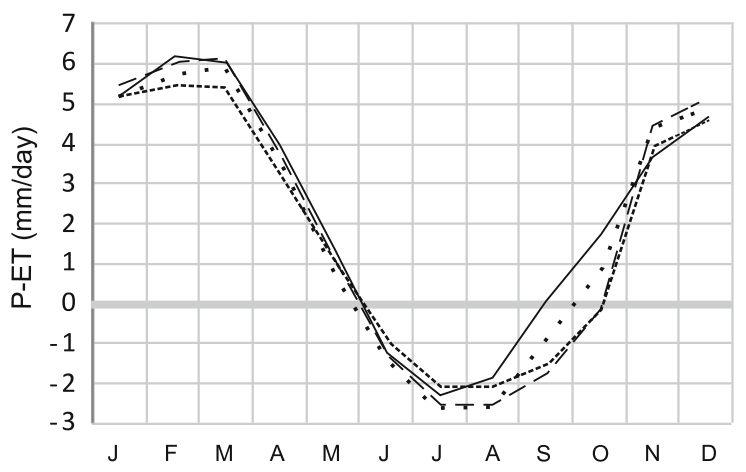

Fig. 4 LCC_CF simulations: the average difference (P-ET) for the period of simulation (excluding the first 2 years) for each scenario and each basin. Negative values represent the water deficit period

Localized deforestation usually causes a direct increase in surface runoff due to ET reduction (Sahin and Hall 1996; Coe et al. 2009) and, depending on the scale of this change, no measurable effect may be observed in regional P. Our LCC_NoCF simulations illustrate this scenario, showing that deforestation can cause a decrease in ET up to $13 \%$ over the Juruá and Purus basins and up to $14 \%$ over the Madeira basin. As a result, river discharge increases by 21, 23 and $31 \%$ in the Juruá, Purus and Madeira rivers, 
respectively. Similar behavior has been observed in other South American basins. For example, deforestation has been associated with observed increases in discharge in the Tocantins River (Costa et al. 2003). Likewise, a study conducted in the Cerrado biome found that two-thirds of the observed increase in the Araguaia River discharge between 1970s and 1990s was due to deforestation (Coe et al. 2011).

On a large scale, climate feedbacks from extensive deforestation may affect atmospheric dynamics, leading to a reduction in P. The LCC_CF simulations demonstrate that large-scale deforestation reduces annual precipitation by up to 15,14 and $10 \%$ over Juruá, Purus and Madeira basins, respectively. If the reduction in $\mathrm{P}$ is large enough, it will offset the decrease in ET, hence reducing surface runoff (Coe et al. 2009) and decreasing river discharge. This is demonstrated from changes in the Juruá and Purus rivers in the LCC_CF simulations, whose simulated discharge decreases by up to 17 and $18 \%$, respectively (BAU2050). In some cases, however, the decrease in ET is still larger than changes in $\mathrm{P}$, leading to increased surface runoff and river flow. This is the case of the Madeira River, whose discharge increases by up to $12 \%$ under BAU2050, even with a $10 \%$ decrease in annual $\mathrm{P}$. The balance between $\mathrm{P}$ and ET can also vary locally, leading to different responses among watersheds within the basin, as demonstrated by increased simulated discharge of the Acre River in the southern portion of Purus basin. The sensitive balance between P and ET under Amazon deforestation scenarios has been the object of various studies. Previous studies have proposed that high rates of ET by the Amazon forest are partially responsible for maintaining local rainfall (Shukla et al. 1990; Eltahir 1996; D’Almeida et al. 2007; Malhi et al. 2008). In addition, Spracklen et al. (2012) showed empirically that water vapor content over forested areas is positively correlated with rainfall downwind.

Impacts of deforestation on precipitation rates can vary seasonally, as pointed out by our LCC_CF simulations, in which the dry season and the transition between wet and dry seasons present greater reductions in $\mathrm{P}$ over the three basins. As a consequence, large-scale deforestation extends the simulated water deficit period (P-ET $<0$ ) in the Juruá and Purus basins (LCC_CF, BAU2050) by one month approximately. These results are consistent with previous studies (Shukla et al. 1990; Nobre et al. 1991; Sampaio et al. 2007; Costa and Pires 2009). Observations in
Rondônia state (Madeira basin) suggest that this process is already causing an 11-day delay in the onset of the rainy season in deforested regions compared to forested regions (Butt et al. 2011).

Implications for ecosystem services

Changes in land cover can lead to non-linear climate and surface interactions that consequently affect river regimes. A large number of ecological consequences could ensue from either increases or decreases in river discharge. These consequences depend on the spatial scales of land cover changes. Considering the local effects of deforestation on surface processes (LCC_NoCF), increased surface runoff and more frequent soil exposure due to forest clearing lead to an increase in sediment and nutrient transport from terrestrial surfaces to the river system (Walling and Fang 2003; Latrubesse et al. 2009). This in turn could alter river morphology, light penetration, dissolved oxygen concentration, and siltation rates as well as shorten the lifetimes of reservoirs and hydroelectric power plants. Due to the importance of rivers for habitats and nutrient transport, changes in water quality and riverbed morphology may alter aquatic ecosystem and fish community structures (Poff and Allan 1995; Gordon et al. 2008; Castello et al. 2013).

Deforested watersheds are also expected to be more prone to peak flows and floods because of reduced infiltration and interception by vegetation, and reduced channel volume due to increased sediment loads. Studies show that deforestation could be linked to an increase in flood frequency and severity and may result in significant economic losses (Bradshaw et al. 2007). The 2012 flood in the Western Amazon illustrates this potential economic consequence. The flood resulted in a direct loss of US\$ 60 million for the city of Rio Branco (Acre, Brazil) alone (Acre Civil Defense data).

Another potential effect of large-scale deforestation, as shown in the results of our simulations with climate feedback, is an increase in the length of the water deficit period. This lengthening, combined with other deforestation-induced changes in the water and energy balance, may exacerbate drought events (Voldoire and Royer 2004; da Silva et al. 2008). This may impact the navigability of rivers, supply of drinking water, and generation of hydroelectric power (e.g. Brown 2006; Marengo et al. 2008). The interaction between deforestation and climate is of particular 
importance for the energy industry, as Amazon countries plan to build large hydroelectric dams throughout the basin. These infrastructure projects may incur economic losses due to indirect impacts on rainfall patterns if deforestation follows business-asusual projections (Stickler et al. 2013). In addition, ranching and agriculture established in deforested areas may have diminished yields (and thus reduced economic rents) in response to reduced precipitation due to forest losses (Oliveira et al. 2013). Extended dry periods also impact the Amazon forest by increasing the occurrence of wildfires (Aragão et al. 2007; Nepstad et al. 2007; Silvestrini et al. 2011) and tree mortality (Laurance and Williamson 2001; Nepstad et al. 2007; Coe et al. 2013)—-thus contributing to increased emissions of greenhouse gases (GHGs) (Phillips et al. 2009; Lewis et al. 2011). The combination of extended dry periods associated with increased drought frequency and forest fragmentation may boost the frequency and severity of forest fires in the Amazon (Silvestrini et al. 2011; Soares-Filho et al. 2012a), potentially accelerating the transition of the Amazon rainforest towards a savanna-like vegetation along its southern edges (Costa and Pires 2009; Malhado et al. 2010). This positive feedback triggered by fire may also alter the water balance and will inevitably lead to biodiversity losses (Foley et al. 2007), with implications for communities and regional economies, hence undermining strategic governmental development plans.

Recent economic losses from droughts can provide some insights on potential future impacts. In 2005, the Southwestern Amazon was the epicenter of a severe drought that reduced river levels to record lows and blocked navigation in many parts (Marengo et al. 2008). Fires burned about 300,000 ha of tropical rainforest and caused economic losses of over US\$ 50 million (Brown et al. 2006). This drought was responsible for the reduction of approximately $1.6 \mathrm{Pg}$ of Amazon carbon stocks (Phillips et al. 2009). In 2010, an even more intense drought spread throughout the Southwestern Amazon, central Bolivia and the Brazilian state of Mato Grosso (Lewis et al. 2011). The forest vulnerability to extreme events, such as floods and droughts, may be aggravated due to feedbacks from anthropogenic climate change. In turn, the combined climatic and hydrological changes due to deforestation will further exacerbate changes from global warming that may be under way (Gloor et al. 2013).
As the land-cover scenarios encompass the entire Amazon landscape, it is not possible to predict how much of the simulated changes in the water balance in the Southwestern basins are due to climate feedbacks from only local deforestation and how much is related to deforestation elsewhere (Coe et al. 2009). In this respect, our study also calls attention to the climatic teleconnections (Avissar and Werth 2005) as a potential 'remote service' provided by forests, highlighting the need for integrated regional conservation policies to maintain broad ecosystem services (Anderson-Teixeira et al. 2012; Coe et al. 2013).

\section{Modeling}

The use of integrated models of landscape and climate processes is at the forefront of Landscape Ecology (Wu 2013). These models help bridge the gap between different scientific approaches and communities in order to better explore and explain complex environmental system dynamics. The assessment of ecosystems service values or economic losses resulting from the disruption of those services may help promote comprehensive plans that harness conservation with sustainable development.

The methods presented here can be applied to other biomes and landscapes-similar studies have been performed in other regions, including West Africa ( $\mathrm{Li}$ et al. 2007) and the Mississippi basin (Donner et al. 2002) - although an interdisciplinary team may be needed to run and interpret the climate, ecosystem, and hydrological models. Flexible and user-friendly modeling software, such as Dinamica EGO (Soares-Filho et al. 2013), can help integrate environmental modelers by providing a platform for sharing models. This type of modeling environment provides straightforward tools and a user-friendly graphical interface that facilitate the assemblage of complex models. As a result, users will be able to apply their own datasets and adapt the models to different spatial scales. In addition, the online coupling of complex climate and/ or dynamic vegetation models to landscape models can be avoided by using climate input data through downscaling techniques (Hewitson and Crane 1996) or metamodels (Simpson et al. 2001).

It is necessary to emphasize that interpretation of model results must take into account uncertainties inherent to the model's physical formulation and parameterization, the experimental design and spatial 
resolution (D'Almeida et al. 2007), and the model's calibration (Hahmann and Dickinson 1997; Voldoire and Royer 2004; Coe et al. 2009). For example, the responses of land surface models (such as IBIS) to deforestation are highly sensitive to the plant biophysical properties, such as plant rooting depth, and soil properties, such as hydraulic conductivity ( $\mathrm{Li}$ et al. 2007; Coe et al. 2009). To date, the parameters values associated with these properties are only partially solved (Imbuzeiro 2010). In the same vein, the simulated climate responses to land-cover changes are a function of a variety of physical and dynamic model processes, particularly over the Amazonwhere the hydrological cycle is tightly coupled with surface energy balance (Da Rocha et al. 2012). Some of the critical processes that represent atmospheric responses to land cover changes are not explicitly solved (parameterized) by climate models (e.g. the formulation for the planetary boundary layer and the cumulus convection; Kiehl et al. 1998). Another limiting factor of climate modeling using general circulation models is related to the spatial resolution, which in most cases is too coarse to adequately represent regional climate features and processes (e.g. meso-scale convective systems; Malhi et al. 2009).

Finally, in our simulations we replace all deforested areas with tropical grass. This is a simplification based on the knowledge that pasture lands are to a great degree the dominant land use on cleared areas in the Amazon (Bowman et al. 2012). Nevertheless, this trend may change in the future as Brazil expands croplands further into the Amazon (Soares-Filho et al. 2012b). Such differences in land use should in the future be addressed by running scenarios with crops explicitly represented (e.g. Kucharik 2003; Osborne et al. 2007; Cuadra et al. 2012).

\section{Conclusion}

The water cycle has been described as the "bloodstream of the biosphere" (Ripl 2003; Gordon et al. 2008), as it transports energy and matter across the earth system. Water integrates surface processes through a common outlet, mediating "flows and transfers between spatial components" (Risser 1995). Modeling water balance and river flows, therefore, serves as a means to investigate in an integrated fashion the cornerstone concepts of landscape ecology: how landscape processes and structure interact and change spatially and temporally (Forman and Godron 1986). Our analysis of the water balance and river discharge under different Amazon deforestation scenarios highlights the importance of forests for regulating climate, water cycling and, consequently, river regimes, improving as a result our "understanding of the effects of changing landscape pattern on local and regional climate processes" (Wu 2013). Future research should focus on the development of methodologies of ecosystem services valuation that include not only the direct benefits of ecosystem protection, but also the indirect ones, such as climate regulation (Anderson-Teixeira et al. 2012) and ecosystem resilience under water-related regime shifts (Gordon et al. 2008).

Acknowledgments We are thankful for the valuable technical support provided by teams at the Centro de Sensoriamento Remoto at Universidade Federal de Minas Gerais (Brazil), Grupo de Pesquisa em Interação Atmosfera-Biosfera at Universidade Federal de Viçosa (Brazil), and The Woods Hole Research Center (USA). We are also grateful to I. Foster Brown and Elsa R. H. Mendoza for the local data provided and Marcia Macedo for language editing. This work was supported by grants from the Gordon and Betty Moore Foundation, the National Science Foundation Division of Environmental Biology, Climate and Land Use Alliance, Fundação de Amparo à Pesquisa do Estado de Minas Gerais, Conselho Nacional de Desenvolvimento Científico e Tecnológico, CNPQProjeto Universal 14/2012, INCT SERVAMB, National Aeronautics and Space Administration, and AMAZONICA Research Project.

\section{References}

Anderson-Teixeira KJ, Snyder PK, Twine TE, Cuadra SV, Costa MH, DeLucia EH (2012) Climate-regulation services of natural and agricultural ecoregions of the Americas. Nat Clim Change 2:177-181

Aragão LEOC, Malhi Y, Roman-Cuesta RM, Saatchi S, Anderson LO, Shimabukuro YE (2007) Spatial patterns and fire response of recent Amazonian droughts. Geophys Res Lett 34:L07701

Avissar R, Werth D (2005) Global hydroclimatological teleconnections resulting from tropical deforestation. J Hydrometeorol 6:134-145

Bonan G (2008) Ecological climatology-concepts and applications. Cambridge University Press, New York

Bowman MS, Soares-Filho BS, Merry FD, Nepstad DC, Rodrigues HO, Almeida OT (2012) Persistence of cattle ranching in the Brazilian Amazon: a spatial analysis of the rationale for beef production. Land Use Policy 29:558-568

Bradshaw CJA, Sodhi NS, Peh KSH, Brook BW (2007) Global evidence that deforestation amplifies flood risk and severity in the developing world. Glob Change Biol 13:2379-2395 
Brooks TM, Mittermeier RA, Fonseca GAB, Gerlach J, Hoffmann M, Lamoreux JF, Mittermeier CG, Pilgrim JD, Rodrigues ASL (2006) Global biodiversity conservation priorities. Science 313:58-61

Brown IF, Schroeder W, Setzer A, Maldonado MLR, Pantoja N, Duarte A, Marengo J (2006) Monitoring fires in Southwestern Amazonia rain forests. EOS Trans Am Geophys Union 87:253-264

Butt N, Oliveira PA, Costa MH (2011) Evidence that deforestation affects the onset of the rainy season in Rondonia, Brazil. J Geophys Res 116:D11120

Castello L, McGrath DG, Hess LL, Coe MT, Lefebvre PA, Petry P, Macedo MN, Renó VF, Arantes CC (2013) The vulnerability of Amazon freshwater ecosystems. Conserv Lett $1-13$

Coe MT, Costa MH, Botta A, Birkett C (2002) Long-term simulations of discharge and floods in the Amazon Basin. J Geophys Res 107(D20):1-17

Coe MT, Costa MH, Howard EA (2007) Simulating the surface waters of the Amazon river basin: impacts of new river geomorphic and flow parameterizations. Hydrol Process 22:2542-2553

Coe MT, Costa MH, Soares-Filho BS (2009) The influence of historical and potential future deforestation on the stream flow of the Amazon river-land surface processes and atmospheric feedbacks. J Hydrol 369:165-174

Coe MT, Latrubesse EM, Ferreira ME, Amsler ML (2011) The effects of deforestation and climate variability on the streamflow of the Araguaia River, Brazil. Biogeochemistry 105:1-3. doi:10.1007/s10533-011-9582-2

Coe MT, Marthews TR, Costa MH, Galbraith D, Greenglass N, Imbuzeiro HMA, Levine NM, Malhi Y, Moorcroft P, Muza MN, Powell TL, Saleska S, Solorzano LA, Wang J (2013) Deforestation and climate feedbacks threaten the ecological integrity of south-southeastern Amazonia. Philos Trans R Soc B 368:20120155. doi:10.1098/rstb.2012.0155

Costa MH, Foley JA (2000) Combined effects of deforestation and doubled atmospheric $\mathrm{CO}_{2}$ concentrations on the climate of Amazonia. J Clim 13:18-34

Costa MH, Pires GF (2009) Effects of Amazon and Central Brazil deforestation scenarios on the duration of the dry season in the arc of deforestation. Int J Climatol 30:1970-1979

Costa MH, Oliveira CHC, Andrade G, Bustamante TR, Silva FA, Coe MT (2002) A macroscale hydrological dataset of river flow routing parameters for the Amazon basin. J Geophys Res 107:D20

Costa MH, Botta A, Cardille JA (2003) Effects of large-scale changes in land cover on the discharge of the Tocantins River, Southeastern Amazonia. J Hydrol 283:206-217

Costa MH, Yanagi SNM, Souza PJOP, Ribeiro A, Rocha EJP (2007) Climate change in Amazonia caused by soybean cropland expansion, as compared to caused by pastureland expansion. Geophys Res Lett 34:L07706

Cuadra SV, Costa MH, Kucharik CJ, Da Rocha HR, Tatsch JD, Inman-Bamber G, Da Rocha RP, Leite CC, Cabral OMR (2012) A biophysical model of sugarcane growth. Bioenergy 4(1):36-48

D’Almeida C, Vörösmarty CJ, Hurtt GC, Marengo JA, Dingman SL, Keim BD (2007) The effects of deforestation on the hydrological cycle in Amazonia: a review on scale and resolution. Int J Climatol 27:633-647
Da Rocha RP, Cuadra SV, Reboita MS, Kruger LF, Ambrizzi T, Krusche N (2012) Effects of RegCM3 parameterizations on simulated rainy season over South America. Clim Res 52:253-265

da Silva RR, Werth D, Avissar R (2008) Regional impacts of future land-cover changes on the Amazon basin wet-season climate. J Clim 21:1153-1170

Delire C, Levis SL, Foley JA, Coe MT, Vavrus S (2002) Comparison of the climate simulated by the CCM3 coupled to two different land-surface models. Clim Dyn 19:657-669

Donner SD, Coe MT, Lenders JD, Twine TE, Foley JA (2002) Modeling the impact of hydrological changes on nitrate transport in the Mississippi River Basin from 1955 to 1994. Glob Biogeochem Cycles 16(3):1043

Eltahir EAB (1996) Role of vegetation in sustaining large-scale atmospheric circulations in the tropics. J Geophys Res 101:4255-4268

Finer M, Jenkins CN (2012) Proliferation of hydroelectric dams in the Andean Amazon and implications for Andes-Amazon connectivity. PLoS ONE 7(4):e35126

Finer M, Jenkins CN, Pimm SL, Keane B, Ross C (2008) Oil and gas projects in the Western Amazon: threats to wilderness, biodiversity, and indigenous peoples. PLoS ONE 3(8):e2932

Foley JA, Prentice C, Ramankutty N, Levis S, Pollard D, Sitch S, Haxeltine A (1996) An integrated biosphere model of land surface processes, terrestrial carbon balance, and vegetation dynamics. Glob Biogeochem Cycles 10:603-628

Foley JA, Asner GP, Costa MH, Coe MT, DeFries R, Gibbs HK, Howard EA, Olson S, Patz J, Ramankutty N, Snyder P (2007) Amazonia revealed: forest degradation and loss of ecosystem goods and services in the Amazon basin. Front Ecol Environ 5:25-32

Forman RTT, Godron M (1986) Landscape ecology. Wiley, New York

Giudice R, Soares-Filho BS, Merry F, Rodrigues HO, Bowman M (2012) Timber concessions in Madre de Dios: are they a good deal? Ecol Econ 77:158-165

Gloor M, Brienen RJW, Galbraith D, Feldpausch TR, Schöngart J, Guyot JL, Espinoza JC, Lloyd J, Phillips OL (2013) Intensification of the Amazon hydrological cycle over the last two decades. Geophys Res Lett 40:1729-1733

Gordon LJ, Peterson GD, Bennett EM (2008) Agricultural modifications of hydrological flows create ecological surprises. Trends Ecol Evol 23(4):211-219

Guo Z, Xiao X, Li D (2000) An assessment of ecosystem services: water flow regulation and hydroelectric power production. Ecol Appl 10(3):925-936

Hahmann AN, Dickinson RE (1997) RCCM2-BATS model over tropical South America: applications to tropical deforestation. J Clim 10:1944-1964

Hewitson BC, Crane RG (1996) Climate downscaling: techniques and application. Clim Res 7:85-95

Imbuzeiro HMA (2010) Parameters estimation of distribution and depth of the root system through the calibration of the micrometeorological models - application to the Amazon rainforest. ScD thesis, Federal University of Viçosa, Brazil

Kiehl JT, Hack JJ, Bonan GB, Boville BA, Williamson DL, Rasch PJ (1998) The national center for atmospheric research community climate model: CCM3. J Clim 11:1131-1149 
Killeen TJ (2007) A perfect storm in the Amazon wilderness: development and conservation in the context of the initiative for the integration of the regional infrastructure of South America (IIRSA). Adv Appl Biodivers Sci 7:105

Kirkby CA, Giudice R, Day B, Turner K, Soares-Filho BS, Rodrigues HO, Yu DW (2011) Closing the ecotourismconservation loop in the Peruvian Amazon. Environ Conserv 38(1):6-17

Kucharik CJ (2003) Evaluation of a process-based agro-ecosystem model (Agro-IBIS) across the U.S. Corn Belt: simulations of the inter-annual variability in maize yield. Earth Interact 7(14):1-33

Kucharik CJ, Foley JA, Delire C, Fisher VA, Coe MT, Lenters JD, Young-Molling C, Ramankutty N (2000) Testing the performance of a dynamic global ecosystem model: water balance, carbon balance, and vegetation structure. Glob Biogeochem Cycles 14:795-825

Latrubesse EM, Amsler ML, De Morais RP, Aquino S (2009) The geomorphologic response of a large pristine alluvial river to tremendous deforestation in the South American tropics: the case of the Araguaia river. Geomorphology 113:239-252

Laurance WF, Williamson GB (2001) Positive feedbacks among forest fragmentation, drought, and climate change in the Amazon. Conserv Biol 15:1529-1535

Lehner B, Verdin K, Jarvis A (2008) New global hydrography derived from spaceborne elevation data. EOS Trans Am Geophys Union 89:93-96

Lewis SL, Brando PM, Phillips OL, van der Heijden GMF, Nepstad D (2011) The 2010 Amazon drought. Science 331:554

Li KY, Coe MT, Ramankutty N, De Jong R (2007) Modeling the hydrological impact of land-use change in West Africa. J Hydrol 337:258-268

Lima Leticia S, Lima Leandro S, Soares-Filho BS, Coe MT, Ferreira BM, Rodrigues HO (2013) Interfaces gráficas em auxílio à implementação e ao uso de modelos hidrológicos. In: Simpósio Brasileiro de Sensoriamento Remoto, Foz do Iguaçu, RS, Brazil

Malhado ACM, Pires GF, Costa MH (2010) Cerrado conservation is essential to protect the Amazon rainforest. Ambio 39:580-584

Malhi Y, Roberts JT, Betts RA, Killeen TJ, Li W, Nobre CA (2008) Climate change, deforestation, and the fate of the Amazon. Science 319:169-172

Malhi Y, Aragao LEOC, Galbraith D, Huntingford C, Fisher R, Zelazowski P, Sitch S, McSweeney C, Meir P et al (2009) Exploring the likelihood and mechanism of a climatechange-induced dieback of the Amazon rainforest. Proc Natl Acad Sci USA. doi:10.1073/pnas.0804619106

Mann CC (2008) Ancient earthmovers of the Amazon. Science 321:1148-1152

Marengo JA, Nobre CA, Tomasella J, Oyama MD, Oliveira GSD, Oliveira RD, Camargo H, Alves LM, Brown IF (2008) The Drought of Amazonia in 2005. J Clim 21:495-516

McClain ME, Boyer EW, Dent L, Gergel SE, Grimm NB, Groffman PM, Hart SC, Harvey JW, Johnston CA, Mayorga E, McDowell WH, Pinay G (2003) Biogeochemical hot spots and hot moments at the interface of terrestrial and aquatic ecosystems. Ecosyst 6:301-312
Meybeck M (1982) Carbon, nitrogen, and phosphorus transport by world rivers. Am J Sci 282:401-450

Millennium Ecosystem Assessment (2005) Ecosystems and Human Well-being: Synthesis. Island Press, Washington, DC

Miller JR, Russell GL, Caliri G (1994) Continental-scale river flow in climate models. J Clim 7:914-928

Mitchell TD, Jones PD (2005) An improved method of constructing a database of monthly climate observations and associated high-resolution grids. Int J Climatol 25:693-712

Mittermeier RA, Mittermeier CG, Brooks TM, Pilgrim JD, Kosntant WR, Fonserca GAB, Kormos C (2003) Wilderness and biodiversity conservation. Proc Natl Acad Sci USA 100:10309-10313

Nepstad DC, Tohver IM, Ray D, Moutinho P, Cardinot G (2007) Mortality of large trees and lianas following experimental drought in an Amazon forest. Ecology 88:2259-2269

Nepstad D, Soares-Filho BS, Merry F, Lima A, Moutinho P, Carter J, Bowman M, Cattaneo A, Rodrigues H, Schwartzman S, McGrath DG, Sticker CM, Lubowski R, PirisCabezas P, Rivero S, Alencar A, Almeida O, Stella O (2009) The end of deforestation in the Brazilian Amazon. Science 326:1350-1351

Nobre CA, Sellers PJ, Shukla J (1991) Amazonian deforestation and regional climate change. J Clim 4:957-988

Nunes F, Soares-Filho BS, Giudice R, Rodrigues H, Bowman M, Silvestrini R, Mendoza E (2012) Environ Conserv 39(2):132-143

Oliveira LJC, Costa MH, Soares-Filho BS, Coe MT (2013) Large-scale expansion of agriculture in Amazonia may be a no-win scenario. Environ Res Lett 8:024021

Osborne TM, Lawrence DM, Challinor AJ, Slingo JM, Wheeler TR (2007) Development and assessment of a coupled cropclimate model. Glob Change Bio 13:169-183

Perz SG, Brilhante S, Brown F, Caldas M, Ikeda S, Mendoza E, Overdevest C, Reis V, Reyes JF, Rojas D, Schmink M, Souza C, Walker R (2008) Road building, land use and climate change: prospects for environmental governance in the Amazon. Phil Trans R Soc B 363:1889-1895

Phillips OL, Aragao L, Lewis SL, Fisher JB, Lloyd J, LopezGonzalez G, Malhi Y, Monteagudo A, Peacock J, Quesada CA, van der Heijden G, Almeida S, Amaral I, Arroyo L, Aymard G, Baker TR, Banki O, Blanc L, Bonal D, Brando P, Chave J, de Oliveira ACA, Cardozo ND, Czimczik CI, Feldpausch TR, Freitas MA, Gloor E, Higuchi N, Jimenez E, Lloyd G, Meir P, Mendoza C, Morel A, Neill DA, Nepstad D, Patino S, Penuela MC, Prieto A, Ramirez F, Schwarz M, Silva J, Silveira M, Thomas AS, ter Steege H, Stropp J, Vasquez R, Zelazowski P, Davila EA, Andelman S, Andrade A, Chao KJ, Erwin T, Di Fiore A, Honorio E, Keeling H, Killeen TJ, Laurance WF, Cruz AP, Pitman NCA, Vargas PN, Ramirez-Angulo H, Rudas A, Salamao R, Silva N, Terborgh J, Torres-Lezama A (2009) Drought sensitivity of the Amazon rainforest. Science 323:1344-1347

Poff NJ, Allan JD (1995) Functional organization of stream fish assemblages in relation to hydrological variability. Ecology 76:606-627

Postel SL, Thompson BH Jr (2005) Watershed protection: capturing the benefits of nature's water supply services. Nat Resour Forum 29:98-108 
Ramankutty N, Foley JA (1998) Characterizing patterns of global land use: an analysis of global croplands data. Glob Biogeochem Cycles 12:667-685

Ripl W (2003) Water: the bloodstream of the biosphere. Philos Trans R Soc Lond B 358(1440):1921-1934

Risser P (1995) The Allerton Park workshop revisited-a commentary. Landscape Ecol 10:129-132

Sahin V, Hall MJ (1996) The effects of afforestation and deforestation on water yields. J Hydrol 178:293-309

Sampaio G, Nobre C, Costa MH, Sayamurty P, Soares-Filho BS, Cardoso M (2007) Regional climate change over eastern Amazonia caused by pasture and soybean cropland expansion. Geophys Res Lett 34:L17709

Shukla J, Nobre C, Sellers P (1990) Amazon Deforestation and Climate Change. Science 247:1322-1325

Silvestrini RA, Soares-Filho BS, Nepstad D, Coe M, Rodrigues H, Assunção R (2011) Simulating fire regimes in the Amazon in response to climate change and deforestation. Ecol Appl 21:1573-1590

Simpson T, Peplinski J, Koch P, Allen J (2001) Metamodels for computer-based engineering design: survey and recommendations. Eng with Comput 17:129-150

Soares-Filho BS, Nepstad DC, Curran LM, Cerqueira GC, Garcia RA, Ramos CA, Voll E, McDonald A, Lefebvre P, Schlesinger P (2006) Modelling conservation in the Amazon basin. Nature 440:520-523

Soares-Filho BS, Moutinho P, Nepstad D, Anderson A, Rodrigues H, Garcia R, Dietschi L, Merry F, Bowman M, Hissa L, Silvestrini R, Maretti C (2010) Role of Brazilian Amazon protected areas in climate change mitigation. Proc Natl Acad Sci 107(24):10821-10826

Soares-Filho BS, Silvestrini R, Nepstad D, Brando P, Rodrigues HO, Alencar A, Coe M, Locks C, Lima L, Hissa LBV, Stickler C (2012a) Forest fragmentation, climate change and understory fire regimes on the Amazonian landscapes of the Xingu headwaters. Landscape Ecol 27(4):585-598

Soares-Filho BS, Lima LS, Bowman M, Hissa LV (2012b) Challenges for low-carbon agriculture and forest conservation in Brazil. Inter-American Development Bank
Environmental Safeguards Unit (VPS/ESG) Technical Notes 2012

Soares-Filho BS, Rodrigues HO, Follador M (2013) A hybrid analytical-heuristic method for calibrating land-use change models. Environ Model \& Software 43:80-87

Southworth J, Marsik M, Qiu Y, Perz S, Cumming G, Stevens F, Rocha K, Duchelle A, Barnes G (2011) Roads as Drivers of Change: Trajectories across the Tri-National Frontier in MAP, the Southwestern Amazon. Remote Sens 3:1047-1066

Spracklen DV, Arnold SR, Taylor CM (2012) Observations of increased tropical rainfall preceded by air passage over forests. Nature 489:282-286

Stickler CM, Coe MT, Costa MH, Dias LC, Nepstad DC, McGrath DG, Rodrigues HO, Soares-Filho BS (2013) Dependence of hydropower energy generation on forests in the Amazon basin at local and regional scales. Proc Natl Acad Sci USA. doi:10.1073/pnas.1215331110

Survival International Charitable Trust (2012) Survival 2012 annual report. http://assets.survivalinternational.org/documents/776/ 2012-final-report-illustrated-pdf.pdf. Accessed 3 February 2013

Swenson JJ, Carter CE, Domec J-C, Delgado CI (2011) Gold mining in the Peruvian Amazon: global prices, deforestation, and mercury imports. PLoS ONE 6(4):e18875

Voldoire A, Royer JF (2004) Tropical deforestation and climate variability. Clim Dyn 22:857-874

Vörösmarty CJ, Moore B, Grace Al, Gildea MP, Melillo JM, Peterson BJ, Rastetter EB, Steudler PA (1989) Continental scale models of water balance and fluvial transport: an application to South America. Glob Biogeochem Cycles 3:241-265

Walling DE, Fang D (2003) Recent trends in the suspended sediment loads of the world's rivers. Glob Planet Change 39:111-126

Wu J (2013) Key concepts and research topics in landscape ecology revisited: 30 years after the Allerton Park workshop. Landscape Ecol 28:1-11 